\title{
Model Inkuiri dan Pendekatan STEM Dengan Proyek Termotolsi Untuk Meningkatkan Hasil Belajar Suhu dan Kalor Pada Peserta Didik Kelas VIIa di SMPN 1 Jenggawah
}

\author{
Yuli Feri Widyawati, S.Pd \\ SMP Negeri 1 Jenggawah \\ E-mail : yuliferiw@gmail.com
}

\begin{abstract}
Abstrak
Penerapan Inkuiri dan pendekatan STEM adalah upaya peneliti untuk melatih peserta didik berfikir ilmiah, agar memahami sains dan teknologi, kreatif berenjiniring, berfikir kritis, cakap dalam operasi matematika, serta dapat bekerja kolaboratif dan cakap berkomunikasi. Dengan demikian maka hasil belajar pengetahuan, keterampilan abad 21 serta karakter peserta didik akan meningkat. Penelitian Tindakan Kelas ini dilaksanakan pada peserta didik kelas VIIA sebanyak 29 peserta didik. Data penelitian yang diambil selama proses pembelajaran menggunakan lembar obervasi. Sedangkan data setelah proses penelitian diambil dengan menggunakan soal soal tes. Melalui analisis hasil penelitian secara kualitatif dan kuantitatif diketahui bahwa, terdapat peningkatan sebesar 7,6 pada hasil belajar pengetahuan, peningkatan sebesar 3,81 pada hasil belajar sikap, dan peningkatan sebesar 12,6 pada hasil belajar keterampilan praktek dan produk, serta peningkatan sebesar 5,8 pada hasil belajar keterampilan presentasi. sehingga disimpulkan bahwa penerapan model Inkuiri dan pendekatan STEM dengan membuat termotolsi dapat meningkatkan hasil belajar siswa
\end{abstract}

Kata Kunci : Hasil Belajar, Model Inkuiri, STEM,Termotolsi

\section{Abstract}

Application of Inquiry and STEM approach is an effort of researcher to train students scientific thinking to understand science and technology. creative enggineering, and critical thinking,competent in mathematical operations, and can work collaboratively and able to communicate. Thus the learning outcomes of students can be improved 21st century skills and character of students will increase as well. This Classroom Action Research was conducted on 29th grade VIIA students. The research data was taken during the learning process, taken using an observation sheet. While the data after the research process is taken using item test. Through the analysis of qualitative and quantitative research results it is known that, there was an increase of 7.6 point in knowledge learning outcomes, an increase of 3.81 point in attitudes learning outcomes, and an increase of 12.6 point in practice skills and product learning outcomes, and an increase of 5,8 point on learning outcomes presentation skills. so it was concluded that the application of the Inquiry model and STEM approach by making thermotolsi can improve student learning outcomes

Keywords : Learning Outcome, Inkuiri Model, STEM, Termotolsi

\section{Pendahuluan}

Suhu dan Kalor adalah salah satu materi yang dipelajari dalam mata pelajaran Ilmu Pengetahuan Alam. Kd ini terdiri atas pembahasan tentang Suhu, Pemuaian zat padat, zat cair dan zat gas, serta pembahasan tentang banyaknya kalor untuk merubah suhu dan merubah wujud zat. Suhu merupakan materi yang rumit karena peserta didik diharapkan dapat mengkonversi berbagai macam skala thermometer. Jika konversi dilakukan secara langsung maka dibutuhkan berbagai macam thermometer, seperti thermometer Celsius, thermometer Reamur, termometer Fahrenheit dan termometer Kelvin. Namun dalam Standart isi menurut Kemdikbud, di harapkan peserta didik dapat menentukan skala yang ditunjukkan oleh berbagai thermometer tidak melalui pengukuran langsung, tetapi melalui percobaan membuat thermometer sederhana dan menyelidiki pengaruh kalor terhadap perubahan suhu dan perubahan wujud benda [1].
Untuk melalukan konversi diperlukan rumus yang bervariasi tergantung skala yang digunakan pada jenis termometer yang dikonversikan. Meski pada pembelajaran sebelumnya di Sekolah Dasar, peserta didik sudah mendapatkan pembelajaran suhu, namun peserta didik kesulitan menghafal berbagai macam rumus konversi suhu. karena rumus yang dihafal terlalu banyak, seperti pada tabel berikut ini :

Tabel 1 : Rumus konversi suhu berbagai thermometer dari :

\begin{tabular}{|c|c|c|c|c|}
\hline & Celcius & Reamur & Kelvin & Fahrenheit \\
\hline Celcius & & $\mathrm{R}=(4 / 5) \mathrm{C}$ & $\mathrm{K}=\mathrm{C}+273$ & $\mathrm{~F}=(9 / 5) \mathrm{C}+32$ \\
\hline Reamur & $\mathrm{C}=(5 / 4) \mathrm{R}$ & & $\mathrm{K}=\mathrm{C}+273=(5 / 4) \mathrm{R}+273$ & $\mathrm{~F}=(9 / 4) \mathrm{R}+32$ \\
\hline Fahrenheit & $\mathrm{C}=5 / 9(\mathrm{~F}-32)$ & $\mathrm{R}=4 / 9(\mathrm{~F}-32)$ & $\mathrm{K}=5 / 9(\mathrm{~F}-32)+273$ & \\
\hline Kelvin & $\mathrm{C}=\mathrm{K}-273$ & $\mathrm{R}=4 / 5(\mathrm{~K}-273)$ & & $\mathrm{F}=9 / 5(\mathrm{~K}-273)+32$ \\
\hline
\end{tabular}

sumber : rumus.com [1]

Padahal berbagai macam rumus konversi suhu tersebut dapat disederhanakan menjadi satu rumus saja yang dapat digunakan untuk mengkonversi berbagai macam thermometer. Cara yang digunakan adalah dengan membandingkan skala termotolsi buatan siswa dengan skala thermometer Celsius. 
Termotolsi adalah thermometer dari botol sirup bekas buatan siswa sendiri. Termotolsi ini terdiri atas botol sirup bekas sebagai dinding thermometer, zat cair pengisi untuk menunjuk skala thermometer, dan selang yang berfungsi sebagai pipa tempat memuai dan menyusutnya zat cair pengisi termotolsi. Selain konversi suhu, Termotolsi juga dapat digunakan sebagai media pembelajaran pemuaian dan kalor.

Untuk konversi suhu digunakan spiritus sebagai zat cair pengisi karena angka muainya tinggi dan warnanya mencolok untuk menunjuk skala. Sedangkan untuk pembahasan pemuaian dan kalor, digunakan zat cair pengisi yang berbeda beda, agar peserta didik dapat mengamati secara langsung perbandingan muai berbagai zat cair pengisi, sehingga dapat melihat besarnya koefisien muai zat dan dapat menemukan rumus pemuaian serta dapat menemukan rumus banyaknya kalor untuk menaikkan suhu dan merubah wujud zat.

Penerapan paduan model inkuiri dan pendekatan STEM dilakukan selama proses membuat termotolsi dan menggunakan termotolsi untuk pembelajaran. Untuk memfasilitasi peserta didik berenjinering, peneliti menerapkan pendekatan STEM, sedangkan untuk memfasilitasi peserta didik menemukan rumus, peneliti menerapkan model pembelajaran inkuiri terbimbing.

Hal ini dilakukan karena pendekatan STEM merupakan pendekatan yang memfasilitasi peserta didik untuk belajar sains dan teknologi dengan tujuan membuat produk melalui tahap enjiniring dan sekaligus mempelajari matematika, karena menurut Poppy Kamalia Devi, STEM merupakan suatu pendekatan dimana Sains, Teknologi, Enjiniring dan Matematika diintegrasikan dengan fokus pada proses pembelajaran pemecahan masalah dalam kehidupan nyata [3]. Sedangkan inkuiri menurut Anam, K adalah model pembelajaran yang memfasilitasi peserta didik untuk menemukan sendiri pengetahuan baru melalui proses berfikir secara sistematis [4].

Dengan pendekatan STEM peserta didik berenjiniring membuat termotolsi kemudian melalui pengamatan pada termotolsi sesuai sintak inkuiri, peserta didik dapat menciptakan sendiri satu rumus yang dapat digunakan untuk mengkonversi berbagai macam thermometer, peserta didik dapat membandingkan koefisien muai berbagai zat pengisi sehingga dapat menemukan rumus pemuaian, dan peserta didik juga dapat menemukan rumus banyaknya kalor untuk merubah suhu dan merubah wujud zat.

Penerapan model inkuiri dan pendekatan STEM dengan membuat Termotolsi untuk menemukan rumus konversi suhu diawali dengan: meminta peserta didik memberikan skala pada termotolsi dengan skala yang seragam yaitu 0 sebagai titik tetap bawah dan 50 sebagai titik tetap atas. Ketika dibandingkan dengan thermometer Celsius , peserta didik dapat langsung menyebutkan bahwa ketika suhu thermometer Celsius menunjuk $50{ }^{\circ} \mathrm{C}$, maka termotolsi akan menunjuk $25^{\circ} \mathrm{C}$. Tanpa menghitung peserta didik dapat menemukan angka yang ditunjuk termotolsi karena skala termotolsi : skala Celsius $=50: 100=1: 2$ atau termotolsi setengah dari Celsius.

Jika ditulis dalam bentuk matematika maka skala termotolsi dibanding skala Celsius $=50: 100 \mathrm{x}$ suhu yang ditunjuk Celsius $=1 / 2 \times 50=25$. Jika ditulis dalam bentuk rumus, maka suhu yang dicari adalah $={ }^{\circ} \mathrm{C}$ (Panjang skala suhu yang dicari / Panjang skala suhu yang diketahui ) $\mathrm{x}$ suhu yang diketahui ${ }^{\circ} \mathrm{C}$

Dengan inkuiri terbimbing, peserta didik menemukan rumus konversi suhu yang berlaku untuk sembarang thermometer. Diawali dengan meminta peserta didik mengganti titik tetap bawah dengan angka bukan 0 sesuai keinginan peserta didik, maka peserta didik daapat menemukan sendiri cara menghitung konversi suhu untuk thermometer yang titik tetap bawahnya bukan 0 dengan menggunakan rumus :

[(Panjang skala suhu yang dicari / Panjang skala suhu yang diketahui ) $x$ (suhu yang diketahui - titik tetap bawahnya) ]+ titik bawah suhu yang dicari .

Rumus diatas dapat digunakan untuk sembarang thermometer dengan sembarang titik tetap atas dan titik tetap bawah. Sehingga peserta didik tidak perlu lagi menghafal banyak rumus konversi suhu. Dengan satu rumus yang berlaku untuk sembarang thermometer maka peserta didik merasa sangat mudah untuk menyelesaikan soal matematika terkait konversi suhu. Satu rumus tersebut juga sangat mudah dihafal oleh peserta didik, sehingga hasil belajar suhu meningkat.

Demikian pula pada pembahasan pemuaian. Peserta didik merasa kesulitan untuk menghafal dan menggunakan rumus pemuaian pada zat padat, zat cair dan zat gas. Padahal rumus tersebut juga dapat disederhanakan menjadi satu rumus saja. Perbedaannya hanya pada angka koefisien muai zat. Dengan membandingkan termotolsi berisi spiritus dengan termotolsi berisi air peserta didik dapat dengan jelas melihat pemuaian pada zat cair pengisi termotolsi. Demikian pula pemuaian pada zat gas yang terperangkap dalam termotolsi. Dengan penambahan suhu sedikit saja udara dalam botol akan memuai kemudian mendorong spiritus naik ke pipa, Sedangkan untuk pemuaian zat padat, peserta didik dapat mengamati botol termotolsi. Dengan menggunakan termotolsi peserta didik akan mudah pula mengetahui bahwa koefisien muai tiap tiap zat berbeda.

Kemudian peserta didik dihadapkan ke permasalahan, jika suhu kawat yang panjangnya satu meter dinaikkan satu derajad, menyebabkan kawat memuai 0,1 m maka jika kawat tersebut dipanasi 5 derajad, akan memuai sebesar 5 x 0,1 . Jika panjang kawat dilambangkan L dan pemuaian per satu derajad dilambangkan $\alpha$, maka pertambahan panjang setelah dipanaskan dirumuskan :

$$
\Delta L=L \times \alpha \times t
$$

Untuk pembahasan banyaknya kalor untuk menaikkan suhu dan untuk merubah wujud zat, rumus ditemukan sendiri oleh siswa dengan membandingkan termotolsi berisi spiritus, dengan termotolsi berisi air. Peserta didik dapat membandingkan bahwa termotolsi berisi air membutuhkan lebih banyak kalor untuk menaikkan suhu dibandingkan termotolsi berisi spiritus. Dari pengamatan ini peserta didik akan memahami pengertian kalor jenis sebagi kalor yang dibutuhkan oleh 1 kilogram zat untuk menaikkan suhunya 1 derajad Celsius.

Setelah memahami kalor jenis, peserta didik dihadapkan pada masalah, misalnya, jika untuk menaikkan satu derajad butuh sepuluh kalor maka untuk naik lima 
derajad dibutuhkan sepuluh kali lima. Jika yang dipanaskan empat kilo maka harus dikalikan empat. Dari masalah ini maka peserta didik akan dapat menemukan rumus besarnya kalor untuk menaikkan suhu. Jika kalor dilambangkan Q, suhu dilambangkan $\mathrm{t}$, kalor jenis dilambangkan $\mathrm{c}$ dan massa dilambangkan $\mathrm{m}$, maka rumusnya :

$$
Q=m \times c \times t
$$

Demikian pula ketika dihadapkan dengan masalah, jika untuk meleburkan es yang massanya sekilo butuh kalor seratus, maka untuk melebur sepuluh kilo es, dibutuhkan sepuluh kali seratus. Dengan cara ini peserta didik dapat menemukan rumus banyaknya kalor untuk merubah wujud zat. Jika massa dilambangkan $m$ dan kalor lebur dilambangkan L maka peserta didik dapat menemukan rumus untuk merubah wujud es menjadi air adalah :

$$
Q=m \times L
$$

Dengan cara yang sama, ketika dihadapkan dengan masalah, jika untuk menguapkan air yang massanya sekilo butuh seribu kalor maka untuk menguapkan sepuluh kilo air, dibutuhkan sepuluh kali seribu. Dengan cara ini peserta didik dapat menemukan rumus banyaknya kalor untuk merubah wujud zat. jika massa dilambangkan $m$ dan kalor uap dilambangkan U maka peserta didik dapat menemukan rumus untuk merubah wujud es menjadi air adalah $\mathrm{Q}=\mathrm{m} \mathrm{x}$ U. Dengan Model inkuiri dan membuat termotolsi sendiri sesuai tahapan STEM, hasil belajar keterampilan dan hasil belajar sikap meningkat demikian pula hasil belajar pengetahuan.

\section{Metode Penelitian}

Penelitian Tindakan Kelas ini dilaksanakan sebanyak dua siklus. Tiap siklus teridiri atas dua pertemuan masing masing masing tiga jam pelajaran dan dua jam pelajaran. Subjek penelitian adalah peserta didik kelas VIIA SMPN 1 Jenggawah sebanyak 29 peserta didik. Waktu penelitian dimulai tanggal 23 september 2019 hingga 3 Oktober 2019. Data diambil dengan teknik observasi,jurnal, tes tulis dan penugasan, lembar penilaian praktek, lembar penilaian produk dan penilaian presentasi. Instrument yang digunakan antara lain : lembar observasi kegiatan diskusi, format penilaian diri, format penilaian antar peserta didik, catatan harian, rubrik penilaian tugas proyek dan rubrik penilaian presentasi, serta soal tes.

Data dianalisis dengan analisa data kualitatif dan analisa data kuantitatif. Hasil alasisis data kualitatif disajikan dalam bentuk naratif, sedangkan data kuantitatif peningkatan hasil belajar peserta didik disajikan dalam bentuk angka.

\section{Hasil dan Pembahasan}

Secara umum penelitian ini mendapatkan hasil berupa peningkatan pada hasil belajar sikap, hasil belajar keterampilan dan hasil belajar pengetahuan. Indikator keberhasilan penelitian ini, pada siklus 1 terdapat $80 \%$ peserta didik telah tuntas dan memperoleh nilai sikap minimal 70, memperoleh nilai keterampilan minimal 70 dan memperoleh nilai pengetahuan minimal 70 . Indikator keberhasilan pada siklus 2 adalah terdapat $80 \%$ peserta didik telah tuntas atau mendapat nilai hasil belajar sikap minimal
75, memperoleh nilai keterampilan minimal 75 dan memperoleh nilai pengetahuan minimal 75 .

\section{Hasil Belajar Sikap}

Secara grafik rerata nilai hasil belajar sikap digambarkan sebagai berikut :

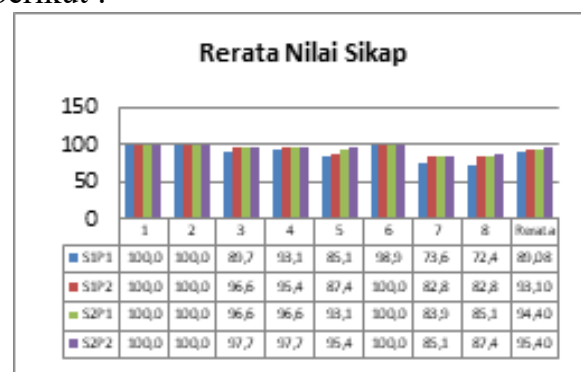

\section{Gambar 1. Grafik Hasil Belajar Sikap Spiritual dan sikap Sosial}

Terdapat 8 butir sikap yang diamati antara lain : 1. berdoa ketika memulai pembelajaran, 2. bersyukur ketika berhasil melakukan tugas, 3. menghargai agama orang lain. 4. kerja sama, 5. menghargai pendapat orang lain, 6. jujur, 7. santun, 8. rasa ingin tahu.

Dibandingkan dengan indicator keberhasilan, rerata hasil belajar sikap pada siklus 1 adalah sebesar $(89,08+93,10) / 2=91.09$, rerata hasil belajar ini sudah melampaui indicator keberhasilan. Rerata hasil belajar sikap pada siklus 2 adalah $(94,40+95,40) / 2=94,40$, melampaui indicator keberhasilan. Rerata tersebut menunjukkan peningkatan pada siklus 2 dari siklus 1 sebesar 3,81.

Hasil Belajar Keterampilan

Pada hasil belajar keterampilan, penilaian terdiri atas hasil belajar praktek dan produk, dan hasil belajar presentasi. Hasil belajar praktek dan produk seperti pada Gambar 2. Pada siklus 1 pertemuan 1 ke siklus 1 pertemuan 2 adalah terjadi peningkatan 22,23. Pada siklus 1 pertemuan $1 \mathrm{ke}$ siklus 2 pertemuan 1 adalah 23,06. Pada siklus 1 pertemuan 1 ke siklus 2 pertemuan 2 adalah 24,35. Rerata siklus 1 dibandingkan dengan rerata siklus 2 terdapat peningkatan sebesar 96,33-83,73=12,6. Rerata nilai hasil belajar praktek dan produk yang diperoleh peserta didik juga telah melampaui indikator keberhasilan. Sedangkan untuk hasil belajar keterampilan presentasi hasilnya dapat dilihat pada Gambar 3 dibawah. Pada hasil belajar presentasi rerata hasil belajar keterampilan presentasi pertemuan 1 siklus 1 bandingkan dengan rerata hasil belajar keterampilan presentasi siklus 2 pertemuan 2, peningkatannya sebesar $=$ $(82,97-74,35)=8,62$, dan rerata peningkatan hasil belajar dari siklus 1 ke siklus 2 adalah 5,38. Rerata hasil belajar presentasi telah melampaui indicator keberhasilan.

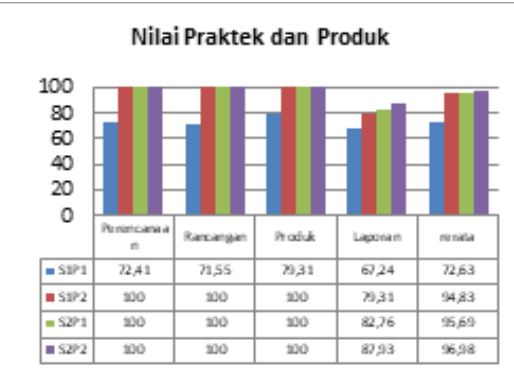

Gambar 2. Grafik Rerata Nilai Hasil Belajar Keterampilan Praktek dan Produk 


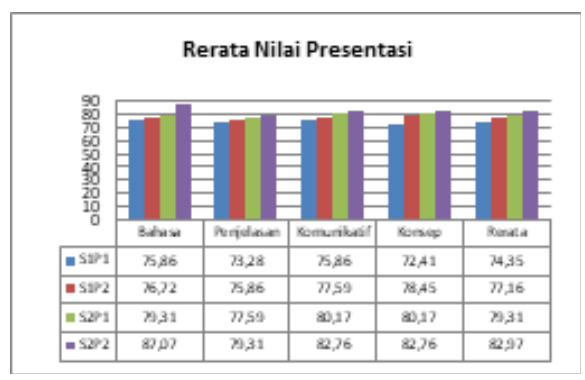

Gambar 3. Grafik Rerata Nilai Hasil Belajar Keterampilan Presentasi

\section{Hasil Belajar Pengetahuan}

Pada hasil belajar pengetahuan, rerata hasil yang diperoleh pada siklus 1 dan siklus 2 menunjukkan peningkatan seperti pada Gambar 4 dibawah
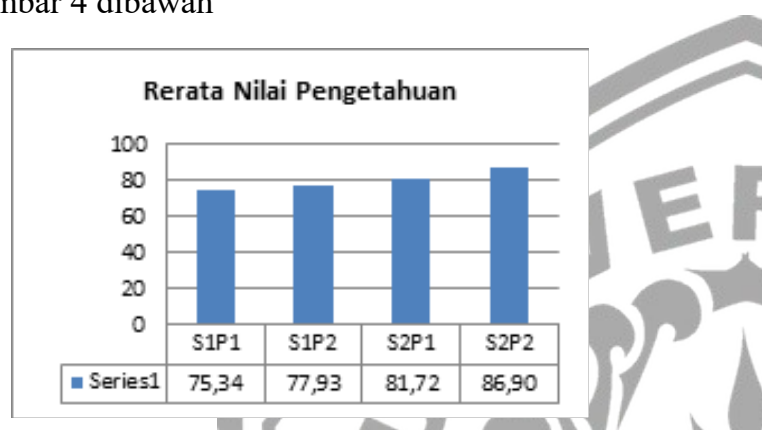

Gambar 4 . Grafik Rerata Nilai Hasil Belajar Pengetahuan

Rerata penguasaan materi suhu dengan menerapkan model inkuiri dan pendekatan STEM dengan membuat termotolsi pada siklus 1 adalah 76,63 dan pada siklus 2 sebesar 84,31. Terdapat peningkatan hasil belajar dari siklus 1 dibanding siklus 2 sebesar 7,68, dan telah melampaui indicator keberhasilan.

Peningkatan hasil belajar pada penelitian ini sangat memuaskan karena telah memenuhi tuntutan kurikulum untuk melatikan cara berfikir ilmiah melalui penerapan model inkuiri dan pendekatan STEM dengan membuat Termotolsi. Tahap berfikir ilmiah menurut kemdikbud adalah tahap tahap yang sering digunakan dalam kegiatan proses ilmiah, antara lain : menanya, mengumpulkan data, menganalis data, dan menyimpulkan kemudian mempublikasikan. Tahapan berfikir ilmiah ini dilakukan dalam kegiatan percobaan atau pengujian, kegiatan teknologi, diskusi kelas dan pemanfaatan lingkungan sekitar [5].

\section{Hasil Penilaian diri}

Hasil penilaian diri yang dinyatakan oleh peserta didik setelah pembelajaran, diketahui $100 \%$ siswa dapat menjelaskan konsep suhu dan perubahannya dengan benar, $100 \%$ siswa sudah dapat menyebutkan skala 3 jenis thermometer dengan benar, $100 \%$ siswa dapat membuat termotolsi untuk menciptakan rumus konversi suhu dengan benar, $100 \%$ siswa dapat menjelaskan penyebab terjadinya pemuaian dengan benar, $100 \%$ siswa dapat menyebutkan contoh peristiwa, pemuaian dalam kehidupan sehari-hari dengan benar, $100 \%$ siswa dapat membuat termotolsi untuk menjelaskan tentang pemuaian pada padat, zat cair dan zat gas dengan benar, $100 \%$ siswa dapat membuat termotolsi untuk menjelaskan tentang pemuaian pada padat, zat cair dan zat gas dengan benar , $93 \%$ siswa dapat menciptakan rumus pemuaian zat padat, zat cair dan zat gas, $100 \%$ siswa dapat menjelaskan faktor-faktor yang memengaruhi banyaknya kalor untuk menaikkan suhu zat dengan benar, $100 \%$ siswa dapat menciptakan rumus persamaan kalor untuk kenaikan suhu dengan benar, $96 \%$ siswa dapat menciptakan rumus banyaknya kalor untuk merubah wujud zat, dan $100 \%$ siswa dapat menjelaskan peristiwa perpindahan kalor : konduksi , konveksi, Radiasi dengan benar.

\section{Kesimpulan dan Saran}

\section{Kesimpulan}

Pelaksanaan penelitian pada pembelajaran dengan menerapkan model Inkuiri dan pendekatan STEM dapat meningkatkan hasil belajar sikap, baik sikap spiritual maupun sikap sosial. Dapat meningkatkan hasil belajar keterampilan praktek dan produk dan keterampilan presentasi, dapat meningkatkan hasil belajar pengetahuan. Dengan Inkuiri terbimbing peserta didik dapat menemukan rumus yang dapat diingat lebih lama dan dipahami. Ketika berhadapan dengan soal soal maka peserta didik dapat menemukan kembali rumus tersebut sehingga dapat memecahkan masalah. Dengan STEM peserta didik dapat belajar sains, teknologi, berenjiniring dan menemukan rumus matematika untuk di terapkan dalam kehidupan sehari hari. Melalui pendekatan STEM, keterampilan abad 21 peseta didik juga dapat ditingkatkan.

Saran

Pembelajaran Suhu dan Kalor pada pembahasan pemuaian, peserta didik kesulitan dalam operasi matematika karena angka koefisien muai terlalu kecil. Untuk membantu peserta didik melihat pemuaian tersebut, dapat digunakan termotolsi sebagai salah satu alternative media . Sedangkan untuk operasi matematika perlu dikenalkan bilangan eksponen agar setelah peserta didik menemukan rumus, siswa dapat menghitung dan menggunakan rumus yang ditemukannya untuk memecahkan masalah.

\section{References}

[1] https://rumusrumus.com/wp-content/uploads/2017/12/tabel-rumuskonversi-suhu, diakses : 23 Januari 2019

[2] Kemendikbud.2013.Materi Implementasi Kurikulum 2013. Jakarta : Kemendikbud

[3] Poppy Kamalia Devi. 2018. STEM Materi Bimtek Pembelajaran Berbasis STEM dalam Kurikulum 2013.Jakarta:Kemendikbud

[4] Anam, K. (2016). Pembelajaran Berbasis Inkuiri: Metode dan Aplikasi. Yogyakarta: Pustaka Pelajar.

[5] Kemdikbud.2013.Pendekatan Scientific (Ilmiah) dalam Pembelajaran. Jakarta:Pusbangprodik 